separate published papers exceeds one hundred, and he is joint author of nearly half as many more with Dr. Harvey B. Holl, F.G.S., Professor W. K. Parker, F.R.S., Dr. H. B. Brady, F.R.S., Mr. J. W. Kirkby, Dr. H. Woodward, F.R.S., Mr. Chas. Davies Sherborn, F.G.S., Dr. G. J. Hinde, V.P.G.S., and others.

From 1850 to 1865 , Prof. Rupert Jones Edited the Quarterly Journal of the Geological Society, and, at the request of the Council, he undertook the editing of the latter half of vol. xlvi. (1890), left unfinished by the lamented death of Mr. W. S. Dallas.

Whether as Lecturer, Professor, Author, or Reviewer, Prof. T. Rupert Jones has always aimed at the advancement of geological science, and although never enjoying a liberal emolument for his professional services, he has never lost his enthusiasm, but laboured on for more than forty years, and is still full of energy and love for that science to which he has devoted his whole life. He has the satisfaction to know that although the pursuit of science is not so remunerative as other professions to which he might have turned his talents, he has nevertheless earned the warm esteem and regard of a very wide circle of friends and fellow-workers who admire his personal character and respect his worth.

\title{
II.-Some Examples of Folds and Faults in the Devonian Rocks at and near Ilfracombe, North Devon.
}

By Henry Hicks, M.D., F.R.S., Sec.G.S.

\section{INTRODUCTION.}

$\mathrm{I}^{\mathrm{N}}$ a paper rear by me before the Geological Society of London on November 26th, $1890,^{1}$ I mentioned that I had obtained evidence during a recent visit to North Devon which had led me to believe that far too little importance had hitherto been assigned to the results of movements in the earth's crust as affecting the succession of the rocks in that area. I mentioned also that the supposed continuous upward succession from the rocks on the shore of the Bristol Channel to those in the neighbourhood of Barnstaple, including, according to some authors, no less than ten distinct groups, was an erroneous interpretation; for the beds are greatly plicated and faulted and several times repeated. Therefore iustead of being one continuous series with a regular dip to the south, the beds are much folded in several broken troughs. In this paper I purpose giving some examples of the folds and faults near Ilfracombe which will enable those who visit that neighbourbood to verify the statements which $I$ have made in regard to some of the rocks in that area. $^{2}$

It will be seen that the beds have been constantly inverted and the folds broken, so that older beds have been made to appear to overlie conformably newer beds. The movements have taken place

1 See Abstract in Proceedings Geol. Soc. No. 562, and Gror. Mag. Dec. 1890.

2 The Morte Slates, which have always been classed as newer than the Ilfracombe beds, I stated in the same paper to be the oldest rocks in the area, and they are now proved by their contained fossils to be of Silurian age. 
mainly in one direction, and the rocks near the fault-planes bave been much sheared.

\section{Combe Martin Bay.}

In the beds along the East shore of Combe Martin Bay from Hangman Point to Combe Martin, there are many instructive examples of folds and faults. From Hangman Point to Wild Pear Beach there is a succession of thick beds of grits and flaggy sandstones which, at and near the point, dip generally to the sonth at an angle of about $35^{\circ}$. Nearer Wild Pear Beach they become bent into sharp folds, and at the north-east corner they are cut across by a fault as shown in Fig. 1. The beds north of the fault are mainly red,

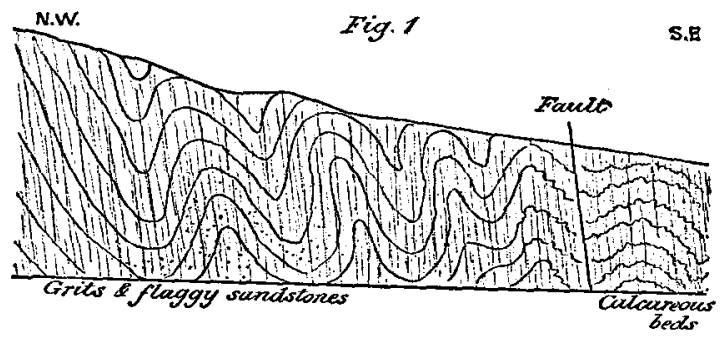

Fig. 1.-Cliff-face N.E. shore of Wild Pear Beach, Combe Martin Bay.

purple, and grey grits and sandstones with some intercalated flaggy beds, but immediately south of the fault flaggy and slaty calcareous beds are met with, here much crushed. In the point which separates Wild Pear Beach from Sandy Bay the flaggy sandstones which, in natural order, overlie the Hangman grits, and which separate the latter from the calcareous beds, reappear bent into acute folds which reach to the top of the cliff, as seen in Fig. 2. Between here and

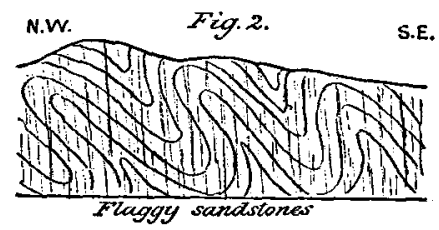

Fro. 2.- Cliff-face N.E. shore of Sandy Bay, Combe Martin.

Combe Martin the beds are greatly folded and frequently broken, but the succession is easily traceable.

The succession, as seen in the cliffs between Hangman Point and Combe Martin Harbour, indicates such an order of deposition as would accompany a gradual depression with a shore-line not far north of the Hangman Point. The lowest or massive grit and sandstone beds are clearly followed in true succession by the finer tlaggy beds, and the latter by slaty and calcareous beds. Certain fossil zones which can be traced often offer evidence to prove that the beds are inverted when the folds are too much broken to be easily followed. Near the crest of the bill north of Combe Martin Church, red and purple grits belonging to the lower or Hangman 
beds are again to be seen under the flaggy beds, hence it is clear that another important fault separates these beds from those exposed in the low ground on the north side, viz., the West Challacombe calcareous beds. The succession as traceable in a section in a line south from Combe Martin shows that the flaggy and slaty beds which underlie the calcareous beds rise up higher and higher in the hills unfil they at list abut agrainst highly cleaved slates of the Morte series type, thereby forming a main trough but containing sereral subsidiary folds with the calcareous beds occupying the highest stratigraphical position.

In following the coast-line from Combe Martin towards Watermouth, numerous folds in the flaggy and in the calcareous beds are recognizable, and the somewhat complex fold (Fig. 3) is seen in a

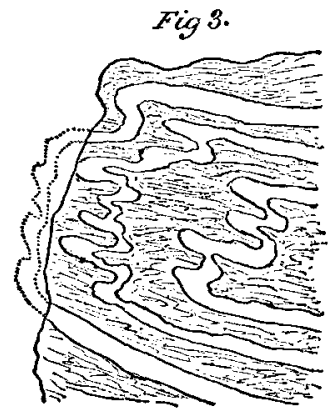

FIa. 3.-Folds in limestone Quarry, road-side, about a mile W. of Combe Martin.

limestone quarry on the roadside, about a mile west of Combe Martin. It will be noticed that the larger folds of the limestone bands, in themselves fairly acute, bave developed, during the pressure, numerous minor folds, and that these have, in places, yielded so far to the pressure that the limbs of the folds have been almost brought together. The movements which have taken place have also nearly obliterated all traces of stratification in the associated argillaceous beds by inducing in them a highly cleaved state. Had this fold been subjected to still greater pressure, it would have assumed the condition frequently witnessed in some of the cliff sections, where, owing to the wearing away of the arch of the fold, band after band seem to lie in true succession, whilst in reality they are but the same band several times repeated in an inverted state.

At the Watermouth Caves, and on the shores of Watermouth Bay, several folds occur in the sandstone and flaggy beds. In the one at the Caves the arch has been broken in a line parallel with the strike, and this produced the line of weakness which subsequently caused the indentation or small harbour which occurs here. Fractures here are most frequent across the middle limb which joins the arch with the trough fold, but this is a good example of the effect of denuding forces acting on a broken arch of ratber rough sediments affected by strong cleavage. 
Hate Bay and Hirlisborodgh.

The beds on the east side of Hele Bay from Rillage Point to Hele Village are, as a rule, intensely folded. The limestone bands are repeated over and over again, and the underlying slates and flaggy sandstone beds are also traceable in broken folds below them. There are also numerous thrust faults which aid in producing the frequent repetitions of the beds. A superficial appearance, owing to the strong cleavage planes, leads one at first to suppose that there is a fairly well-marked succession with a general dip to the south, but a closer examination shows how entirely deceptive this is. The more one examines the beds on this coast, the more one is constantly reminded of the intensely complex arrangements which have been produced by earth-movements. The results in indncing cleavage and foldings on a small scale, in some of the sediments in this area, have been already referred to by Dr. Sorby, F.R.S., ${ }^{1}$ and by Mr. J. E. Marr, F.R.S., ${ }^{2}$ but I was entirely unprepared to find here evidences of such remarkably deceptive appearances in regard to the general succession which gradually made themselves apparent during my researches.

On the west side of Hele Bay the beds are bodily thrown forward by a fault which crosses the beds more or less in the line of the Valley. The section on this side passing through Hillsborough is most instructive as illustrating mountain-making by a series of parallel folds aided by thrust faults, especially as the beds can be examined in cliff sections in Hele Bay on the one side, and also in the precipitous cliffs and coves on the Ilfracombe side. Extending across the hill from the point between Rapparee Cove and Larkstone Beach are fairly gentle folds of sandstone beds, but between here and Beacon Point the folds become steeper and steeper, and at last are so much crushed and broken that the limestone bands in the higher beds near the Point are so cleaved as to look, at a little distance, like slates.

If the section is catried in a line south from Hillsborough it will be found that similar beds to those which form that hill are repeated in wider folds here and there broken across, but which on the whole form themselves into a fairly wide trough in which the sandstone beds mark the boundary on the south at a fault which separates the Ilfracoimbe beds from the Morte series.

\section{ILFRACOMBE.}

Lantern Hill and Capstone Hill, Figs. 4, 5, and 6, offer illustrations of fairly gentle folds broken on the north or seaward side; the result being a precipitous face on the over fold or broken side and an easy slope on the side of the arch limb. These show the conditions to be witnessed in the majority of the Torrs which are so plentiful in the neighbourhood, especially those formed of the

1 Q.J.G.S. vol. xxxv. pt. 2, p. 89.

2 Geol. Maq. 1888, Decade III. Vol. V. p. 218. 
Dr. Henry Hicks-Folds and Faults in N. Devon Rocks.

massive sandstone beds, which of necessity are of a somewhat unyielding character. These folds also are frequently fractured in lines radiating outwards more or less from the core of the fold, which are quite independent of the cleavage planes. The lateral pressure which has been sufficient to produce these effects on the harder and unyielding

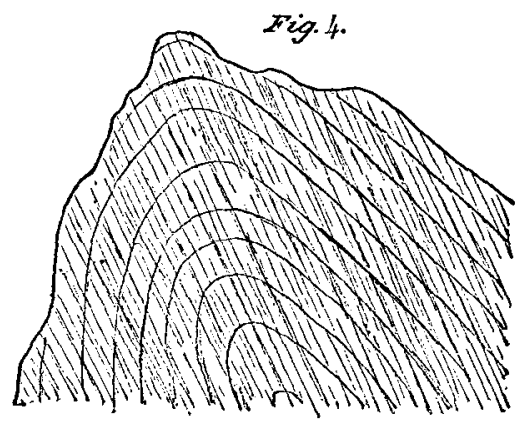

Frg. 4.-Fold in flaggy beds on the shore between Capstone Hill and Lantern Hill, llfracombe.

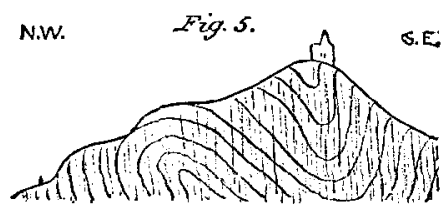

FIG. 5.- Seetion through Lantern Hill, Ilfracombe.

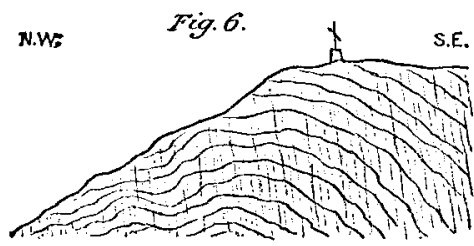

Fra. 6.-Section S. W. face of Capstone Point.

beds, has, as has already been stated in the case of the beds at Hele Bay, affected the softer and more yielding calcareous beds in a far more marked manner. There are many excellent examples of folds in the harder beds on the shore at Ilfracombe which may be easily exanined, and which

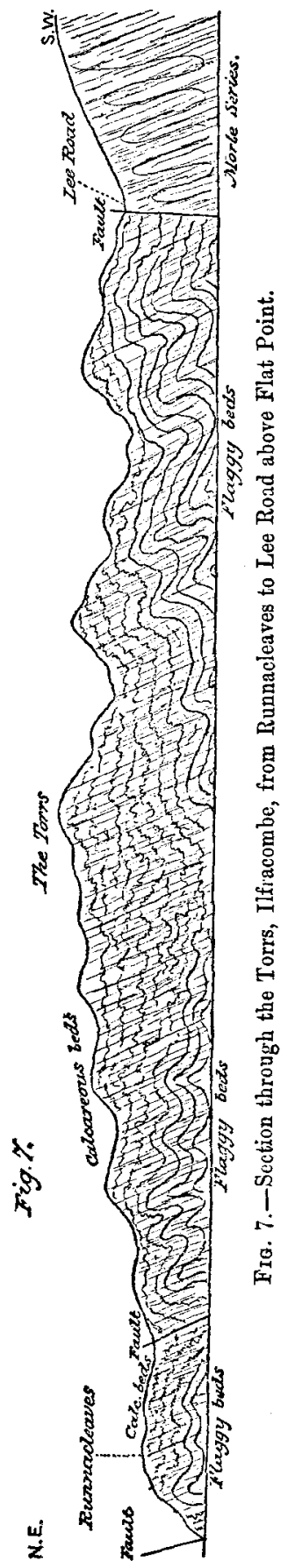


exhibit in a marked manner the influence of intense pressure on sandstone and argillaceous material. There are those already referred to on each side of the Rapparee Cove, in the Lantern Hill and in the Capstone Hill, as well as the fold (Fig. 4) between the Capstone and Lantern Hills, and another interesting example on the shore under the Ilfracombe Hotel, all of which can be reached with ease. The glossy appearance of these rocks readily strikes the eye, and on examination it will be found to be due to the combined effects of shearing and of subsequent infiltrations along the crush lines. At Wildersmouth between the Capstone Hill and the Ilfracombe Hotel a fault crosses the beds, which, although not of much importance in regard to the question of succession, is yet interesting as showing the influences produced by cross faults on the physical features of a district, for most of the harbours and valleys in this area have had their direction determined by these faults as being the lines which offered the least resistance to denuding agencies.

Fig. 7 is intended to illustrate the general succession as traceable in the cliffs under the Torrs from near the Ilfracombe Hotel to the ridge beyond the last of the 'Torrs. At the north end of the section there is the sharp fold in the sandstone beds broken on the north side and much seamed with quartz veins in the line of the thrust fault. This is best seen, as already stated, under the Hotel grounds, but it is equally well shown at the Point outside the ladies' bathing place, where inverted and jagged-looking beds on the north side of the fold form a well-marked ridge. The beds at this horizon are freely covered with worm-tracks, and these offer an easy means of finding out whether the beds are inverted or not when the arch has disappeared. Overlying these beds at the bathing-place are the grit, argillaceous and calcareons bands which were described by Dr. Sorby as illustrating the development of slaty cleavage, and more recently by $\mathrm{Mr}$. Marr, ${ }^{1}$ to show some effects of pressure on sedimentary rocks. These beds being composed of softer and more yielding materials than the underlying beds, have given way much more readily to the pressure, and the result has been to induce a strong cleavage in the argillaceous beds which has, as seen in Fig. 8 , nearly

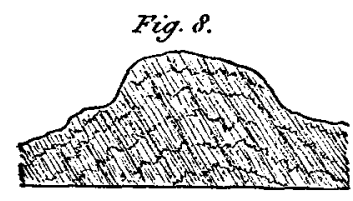

Fra. 8.-Cleavage nearly obliterating bedding in slaty beds, quarry, Torr's Park Road.

obliterated all evidence of stratification, and which bas broken the limestone and also some quartz bands into lentioular fragments having their long axes parallel with the cleavage planes.

Beyond this point the calcareous beds rise higher and ligher in the cliff, and at last form the central group of Torrs. The Torrs

\footnotetext{
1 Grol. MAG. 1888, Decade III. Vol. V. p. 218.
} 
further south are, in the main, composed of sandstones and flaggy beds, but with some of the slaty and calcareous beds also folded in. The sandstone beds may be easily examined on the Lee (Cliff) Road at the junction of the Upper Torr's Walk with the Lee Road, and also on the coast below the last two Torrs. In the eliff, north of Flat Point, the beds are much crushed, and show clearly that there is an important, fault separating the beds which compose the Torrs from the highly cleaved slates of the Morte series, which form the high ridge on the south side which intervenes between here and Lee.

It will be seen that the interpretation here given of the succession along the Torrs, and elsewhere in the Ilfracombe district, differs in a very marked manner from that generally adopted. Instead of interpreting the Tor's as formed of outcrops in a succession of hard and soft beds having a regular dip to the south, they are here shown to be due to foldings and fractures of the strata, the wider Torrs with even slopes on the south side being formed mainly of hard and unyielding beds, and the smaller and less regular ones of softer argillaceous and calcareous rocks. The realization of these facts will necessitate, in future, a great reduction in the thickness hitherto given to the Ilfracombe series, and the re-arrangement of the fossil zones. These points will be dealt with further in a forthcoming paper, which will include also the description of the Morte series and its fauna. The Morte slates have been described as entirely barren of organic remains. My researches have now proved that they are everywhere fossiliferous, and that they contain a fairly rich fauna.

\section{III.-Eskdale Drift and its Bearing on Glacial Geology.}

By T. Mellard Reade, C.E., F.G.S., etc.

PART I.

THE extraordinary abundance and almost universal distribution of fragments of Eskdale granite through the Drift of the North-West of England and part of North Wales is an impressive fact to the student of Glacial Geology. Mackintosh was the first to systematically trace this rock through the Drift and to note its origin. Since the time of this single-minded and patient investigator many other geologists have gone over the same ground and extended his observations, and all must bear witness to the accuracy of his facts.

In this paper I propose to speak only of the facts of Glacial Geology which I have personally observed, so that absence of reference to the work of others must not be construed into insensibility to their merits. Indeed, were I only to name all the meritorious workers even in this area of Great Britain the space at my disposal would prove all too short.

\section{Distribution of the Eskdale Granite.}

In almost every section of Drift from St. Bees, in Cumberland, to the south of Shropshire, and from Macclesfield across to Wales, and 